\title{
Jesus and the Repentance of E. P. Sanders ${ }^{1}$
}

\author{
Bruce D. Chilton
}

Is 'the repentance of E. P. Sanders' the repentance he refers to or the repentance he might undergo? 'Of' in my title can represent a subjective genitive, in which case the views which belong to Sanders would be at issue. But the preposition might also represent an objective genitive, in which case Sanders would be portrayed as influenced by repentance (at least potentially). The distinction between the subjective and the objective genitive, although frequently important, can be difficult to draw. Paul is notoriously vague in this regard, as when he speaks of 'the gospel of Christ' (and similar phrases): is it Jesus' preaching or an account concerning Jesus he has in mind? To exclude either meaning from Paul's mind would be a distortion, but the particular context of a usage permits the reader to judge which emphasis is paramount in a given case. My title indulges a Pauline ambiguity, but I intend to be more predictable than Paul was.

Essentially, my concern is to describe Sanders's views in respect of Jesus and repentance, and that description will lead to the identification of a problem within them (' 1 . Description'). In order to understand the genesis of that problem, I propose to analyze how it arose, and where a perfectly sound argument began to go astray ('2. Analysis'). To that extent, the bulk of my remarks would correspond to a reading of my title as a subjective genitive. The fact is, however, that the description and analysis of Sanders's views has brought me to suggest that he and his readers might reasonably alter them. To that degree, my concluding section is styled as paraenetic ('3. Paraenesis'), and the genitive of my title has a double edge. I should say from the outset, however, that I regard Sanders's contribution as seminal. An unashamedly historical approach to Jesus is today again being

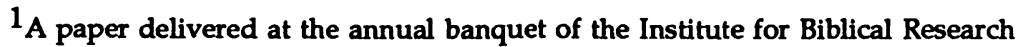
on 4 December 1987, and dedicated to the memory of Colin Hemer - my first friend at Tyndale House, and briefly my colleague in Sheffield. 
explored, and early Judaism is seen as Jesus' natural milieu; in both these aspects, Sanders has helped shape the present state of the discipline. Precisely in view of his influence, a critique of a problematic feature within his thought appears appropriate.

\section{Description}

Among the theses presented in his recent book, Jesus and Judaism, none is more controversial than Sanders's notion that Jesus did not preach repentance. He defends his approach by means of the argument that the evidence of passages which have Jesus refer to repentance is 'relatively speaking, slight', by which he means that they may have been subjected to a degree of Christian interpretation. ${ }^{2}$ On Sanders's understanding, 'There is a puzzle with regard to Jesus' view of sinners: we do not know just how he expected them to live after their acceptance of his message. ${ }^{3}$ That problem, taken in the context of his entire book, appears somewhat artificial, in that it is caused by Sander's rejection of the very evidence that would have solved it.

Sanders builds a great deal on his finding; he argues that Jesus offered the Kingdom to the wicked without repentance. ${ }^{4} \mathrm{He}$ is well aware that parables such as that of the lost sheep, in Matthew 18.12-24 // Luke 15.4-7, concern repentance, but apparently individual repentance. ${ }^{5}$ He does not appreciate, it would seem, that the controlling metaphor involves God as a shepherd and Israel as his flock, as is consistent with biblical usage and Jesus' metaphorical habits (cf. especially Ezekiel 34 and Mt. 25.31-46). Sanders's sharp distinction between individual and communal repentance cannot be maintained, precisely because we are dealing with a collective image. He is correct in saying that there is not a significant body of reliable sayings materials which explicitly

2 E. P. Sanders, Jesus and Judaism (London: SCM and Philadelphia: Fortress, 1985) 109.

3 Sanders (1985) 283.

4 Sanders (1985) 187, 199, 206-7, 227.

5 Sanders (1985) 111. 
attributes to Jesus a call for national repentance, ${ }^{6}$, but only if the italics in that statement are carefully observed. Even then, it is surely appropriate to bear in mind that Jesus was in no position himself to address Israel generally, as occurs in the published documents of early Judaism: his own words were addressed to particular hearers on specific occasions. When Jesus did approximate to that position, by means of his commissioned disciples, it is notable that they preach in order that people might repent' (Mk. 6.12). Sanders takes that statement, and those like it, as 'editorial', 7 and it clearly is of a summary nature (whatever its provenance). But to argue on that basis that Jesus did not emphasize repentance is curious in the extreme: the operating assumption would seem to be that Jesus stood for the opposite of everything that is interpretative in the Gospels.

Sanders is well aware of the oddity of his position. He acknowledges that repentance was an aspect of the conventional theology of early Judaism, and that John the Baptist emphasized it. ${ }^{8}$ On both counts, one would have expected Jesus to have accepted repentance as part of his normal, religious vocabulary. Instead, Sanders claims that, 'in view of the eschaton he simply did not deal in detail with their [sc. his hearers] behaviour, and thus could truly be criticized for including the wicked in his "kingdom"'.9 Such a judgement can only be reached by programmatically excluding evidence, as we have already seen, and in addition by ignoring the ethical themes of the parables. In the Kingdom the parables convey, the farmer must be punctual, ready and swift

\section{Ibid.}

7 Sanders (1985) 109, 113. The evaluation of such material is crucial for any historical assessment of Jesus. Interpretative developments, which explain his actions or sayings, are at every turn provided together with more primitive material, so that the removal of everything that is 'editorial' would create a vacuum, not a solution (Cf. my earlier work, God in Strength. Jesus' Accouncement of the Kingdom, now reprinted in 'The Biblical Seminar' of the JSOT Press [Sheffield, 1987]. The simple fact of the matter is that the most 'editorial' of statements is evidence of Jesus' impact upon his followers; simply to discount their assessment of him, in favour of our own hypotheses, hardly seems critical.

8 Sanders (1985) 112, 332.

9 Sanders (1985) 323. 
to benefit from harvest (Mk. 4.26-29); discoverers of treasure and of pearl must be prepared to sell everything to acquire them (Mt. 13.44-46); potential guests must heed invitations, give up their normal activities, and be properly attired when the hour for feasting arrives (Mt. 22.1-10 // Lk. 14.15-24; Mt. 22.11-14). Penitent renunciation is certainly not demanded for its own sake, but it is implicit within a positive response to the Kingdom as supremely valuable: if the Kingdom is worth everything, it might come at the price of everything. Repentance, a turning back to what alone has value, is a necessary and inescapable aspect of entering the Kingdom; it is implicit within much of Jesus' discourse, and need not be named to be operative.

The motif of 'entering' the Kingdom, which is so signal within Jesus' sayings, itself illustrates an ethic of penitent response. It is a metaphor sometimes of a seemingly impossible struggle, perhaps more difficult than a camel squeezing itself through a needle's eye (Mt. 19.24 // Mk. 10.25 // Lk. 18.25), or as vexing as becoming children again (Mt. 18.3 // Mk. 10.15 // Lk. 18.17; see Jn. 3.3-4). In both cases, the language of the Kingdom is employed to insist that there is a presently realizable way of accepting God. The king rules even now, and obedience to him constitutes entry into his Kingdom, and the rich promises of that Kingdom. But wealth is an obstacle to entry, and even the status of adulthood must be given up in childlike responsiveness. Although the commands to enter the Kingdom are not parables, in the sense in which that word is normally used, they involve the use of metaphor in order to convey an ethical theme by means of one or more motifs, just as the parables do. For that reason, they also belong within the category of the linguistic performance of the Kingdom by Jesus. What characterizes that performance, among other things is a fit between imagerial motif and ethical theme, to which Sanders's thesis does less than justice. His thesis simply discounts too much material which refers to repentance explicitly, and clashes too much with material which implies the necessity of repentance, to be convincing. 


\section{Analysis}

Sanders does not develop his distinctive view of Jesus' perspective upon repentance because he interests himself in that subject per se. Rather, he is concerned with what is, in the first instance, a narrower question. It is perhaps for that reason that his thesis suits the entire run of material to which it should do justice only with difficulty. In 1983, Sanders's article, 'Jesus and the Sinners' was published in Journal for the Study of the New Testament, as part of a Festgabe for Ernst Bammel. ${ }^{10}$ That publication is the nucleus of the relevant chapter within Jesus and Judaism, entitled 'The Sinners', and is more redolent of the inquiry which produced the thesis than is the larger work. Sanders's primary preoccupation in his article is to explain the charge against Jesus that he associated with sinners, a charge which Sanders argues was actually made against Jesus, and plausibly made. In a seminal and exacting review of the then current consensus, and the contribution of Joachim Jeremias within it, Sanders successfully alters the shape of our discipline for the foreseeable future. He does so by means of a trenchant critique of Jeremias's work.

The consensus established by Jeremias may easily and quickly be described. Jesus is portrayed as attacked by Pharisees who are essentially haverim: they insist that table fellowship be extended only to those in that degree of cultic purity which would be appropriate to meals in the Temple. In breaking with that movement, Jesus also associated with cultically impure 'sinners', as his mission of reconciliation demanded. ${ }^{11}$ Sanders doubts that the Pharisees were concerned primarily with such issues of purity, and instead conceives of them generally as a party devoted to the Torah in its oral explication. Accordingly, issues of purity are within Sanders's perspective 'ritual and trivia', two words which he apparently uses epexegetically. ${ }^{12}$ But if the 'sinners' Jesus eats with are not

10 E. P. Sanders, Jesus and the Sinners', JSNT 19 (1983) 5-36.

11 Sanders (1983) 7, 8; Sanders (1985) 176, 177.

12 Sanders (1983) 11-15; Sanders (1985) 179-88. The linking of the two words in several forms appears in (1983) 11 and (1985) 180, 187, 210. Sanders refers to 'ritual and trivia' first when he characterizes the tendency of scholarship to 
merely impure, why are the Pharisees offended? Sanders realizes that an answer to the question must be offered, if his attack on Jeremias is to prove successful. His reponse is bold, and provides the vitally fresh contribution of Jesus and Judaism. Sanders argues that Jesus offered companionship to the wicked of Israel as a sign that God would save them; he did not make his association dependent on their conversion to obedience to the law.' ${ }^{13}$ That, to Sanders's mind, explains the offence of Jesus' contemporaries at his fellowship with 'tax collectors and sinners': he did not require repentance from them, at least not in the usual sense. Where Judaism generally required sacrifice and restitution, as tokens of genuine repentance, Jesus required only obedience to his own message. To that extent, Sanders argues that the authorities who put Jesus to death acted in a manner consistent with received Judaism, in

equate the Pharisees with the baverim. Of course, he rejects that equation, but in so doing he consigns the issue of purity to puritanical 'minutiae' (cf. [1985] 187). He permits himself, in other words, to be pressed into an equation of 'ritual' and 'trivia' in his zeal not to trivialize Judaism. His aim is laudable, but his argument forces early Judaism into the model of an ideological, rather than a cultic system. Such a model is simply anachronistic.

13 Sanders (1983) 26; Sanders (1985) 207. Sanders wrote both his article and his book from an expressly historical perspective. But he is clearly aware of the theological implications of his thesis. Sanders's earlier work, Paul and Palestinian Judaism (cf. n. 19) taxes scholarship for characterizing Judaism as legalistic. Instead, he uses the phrase 'convenantal nomism' to describe it. The change involves more than the substitution of Greek nomos for Latin lex: the point in Sanders's mind is that law in Judaism is not a means of earning favour, but the instrumentality of abiding within God's gracious covenant. But having offered that useful insight, Sanders persists in understanding Jesus and Paul as in polar opposition to a central tenet of Judaism. Where earlier scholarship portrayed the polarity as works and grace, Sanders takes it as covenant and universal inclusiveness. Moreover, Sanders pairs Jesus and Paul in contrast to early Christianity generally, and so provides - in effect - a new account of the essence of Christianity. The radical, practically antinomian teaching of the founders is rejected by Judaism and subverted by Christianity. The plainest exposition of Sanders's overall pieture is available in 'Jesus, Paul, and Judaism', ANRW 25.1 (ed. W. Haase; Berlin: de Gruyter, 1982) 390-450. The similarity with the romanticism of Adolf von Harnack is striking (cf. W. G. Kümmel [tr. S. McL. Gilmour and H. C. Kee], The New Testament. The History of the Investigation of Its Problems [London: SCM, 1973] 178-84). 
that Jesus could rightly be said to offer the Kingdom to the wicked. ${ }^{14}$

The chief strength of Sanders's analysis is that it replaces a point of view which hopelessly caricatures Judaism. The opposition to Jesus becomes plausible, on Sanders's reconstruction; on Jeremias's reading (and others'), the understanding was that some took offence at Jesus because he offered repentance to those who were regarded as unacceptable. Sanders rightly recognizes, and amply demonstrates, that there could have been no plausible objection to promulgating repentance among those who required it. ${ }^{15}$ To argue such a case is more a theologoumenon of Christian faith in its popular form than a defensible analysis of Judaism: it makes Judaism hopelessly formalistic in order to make the common sense of Christianity look gracious. ${ }^{16}$ In Sanders's estimation, the construal of repentance by Jeremias, along with the 'ritual and trivia[1]' reference to purity as the issue of contention, both need to be set aside.

While the strength and vigour of Sanders's case are apparent, there are also implicit within it a series of weaknesses and inexactitudes. The first and most obvious of them, as has already been indicated, is that only a tendentious reading of the sources can bracket the message of repentance from Jesus' preaching. Time and again (as we have seen), Sanders must dismiss as 'secondary' passages which do not suit his case, plead that the repentance demanded by Jesus is not of a 'national' order, insist that when Jesus did speak of repentance, he meant it in a new (and offensive) way. The implications of his own thesis are particularly troubling to

14 Sanders (1985) $187,199,206,207,208,227$. In a damaging admission on p. 203 , Sanders allows that the parables of the lost sheep, the lost coin, and the prodigal son (Lk. 15.1-32) may implicitly suppose that repentance is the appropriate response to the divine action which is portrayed. By the end of his book, Sanders speaks of Jesus as not emphasizing repentance, rather than as excluding reference to it altogether (p. 322, cf. also p. 205). At that point, historical plausibility -- on which Sanders sets great store - is destroyed; that Jesus mortally offended his contemporaries over a matter of inflection is less than credible (see below).

15 Sanders (1985) 203-6; Sanders (1983) 23-6.

16 Sanders (1985) 199-202; Sanders (1983) 20-2. 
Sanders. He cannot explain, and admits that he cannot, what Jesus expected people to do after associating with him, since apart from 'repentance' in some normally accepted sense, the ethical content of his preaching is scarcely fulsome. ${ }^{17}$ What is even more perplexing to Sanders is that Jesus, a follower of the Baptist (whose message focused on repentance), should have such a signal lacuna in his preaching. He resolves that dilemma to his own satisfaction by arguing that Jesus did not stress repentance, although he did assume it (cf. n.14).

At precisely the development of the last qualification, Sanders's scheme strains credibility to breaking point. He is himself especially scathing about any attempt to construe the debate between Jesus and his contemporaries as the alternative between forgiveness leading to reformation and reformation occasioning forgiveness. That distinction, as Sanders sees it, is a modern nicety: the crucial issue within early Judaism is simply whether the integrity of Torah is maintained. ${ }^{18}$ But if Sanders is convincing in that regard, his analysis returns to haunt his own conclusions, in that he would have us believe that the antagonism towards Jesus, and ultimately his death, came about as the result of a mere emphasis within his preaching. There hardly seems a world of difference between saying that Jesus died for a specific view of repentance, and saying he died for the inflection of repentance within his preaching generally. Indeed, the former alternative may be preferred, as offering at least the reasonable prospect of substantial contention; the latter appears ineluctably subjective.

The present position appears to be that Sanders has posed a crucial question, which reveals the relative inability of our discipline to explain the deadly opposition to Jesus, but that his own attempt at explanation does not represent progress. In order to press beyond the impasse, a further consideration of the root of Sanders's confusion may prove productive. A shift in vocabulary occurs, in both his article and his book, which proves to be fundamental to his argument.

17 Sanders (1985) 283.

18 Sanders (1985) 204, 205. 
Sanders relates the term 'sinners', in the accusation that Jesus' fellowship included the unsavoury, to the word 'wicked' in Hebrew (resa'im), which Sanders construes to be a technical term for those outside the pale of Judaism. No argumentation

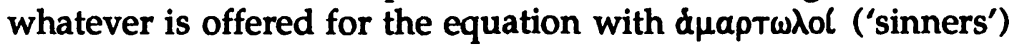
in the Gospels, apart from a reference to Sanders's earlier volume, Paul and Palestinian Judaism. ${ }^{19}$ The discussion in that

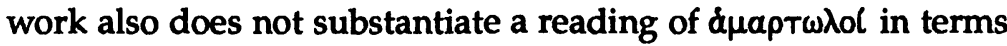
of resa'im, although it does establish that 'the wicked' are, on the whole, scheduled more for punishment than for repentance. The central, linguistic equation of Sanders's case, however, remains unexamined. From the point of view of ordinary, exegetical practice, that is the Achilles' heel of the thesis under consideration.

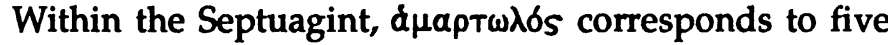
roots in the Masoretic Text (ht', hnp, $h r^{\prime}, r^{\prime}, r s^{*}$ ), only one of which would support the equation proposed by Sanders. ${ }^{20}$ When the probabilities of translation into Aramaic are also taken into account, that equation appears difficult to sustain. The root of $r s^{\prime}$ does appear in the Isaiah Targum, both adjectivally and as an abstract noun. The roots $r \xi^{\circ}$ and $h n p$ are represented by the Aramaic usage but the other three equivalents of $\alpha \mu a \rho T \omega \lambda \delta s$ are not. ${ }^{21}$ Clearly, the linguistic

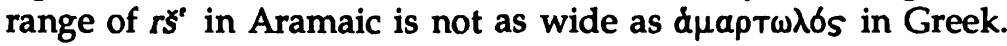
By contrast, the Hebrew roots $r r^{\prime}, h n p$, ht', and several others are represented by appropriate forms of the Aramaic $h w b$ ' (or its verbal equivalent, $h w b$ ): 'debtor', or 'sinner', is the functional equivalent of words covering a variety of defects in the Masoretic Text. When the semantic range of Targumic $h w b b^{\prime}$ is considered, two features of the usage are immediately

19 With the subtitle, A Comparison of Patterns of Religion (Philadelphia: Fortress and London: SCM, 1977) 142f., 203, 342-5, 351-5, 357f., 361, 399-405, 414. The work is cited in Sanders (1985) $386 \mathrm{n} .16$.

20 E. Hatch and H. A. Redpath, A Concordance to the Septuagint (1897, reprinted Athens: Beneficial, 1977) 64, 65. Sanders's review of the evidence of the Septuagint is so incomplete as to be misleading, cf. p. 342. The simple fact is that duaptwiós is used too flexibly to be equated with any 'technical term' of restricted meaning, as Sanders ([1985] 177) claims.

21 J. B. van Zijl, A Concordance to the Targum of Isaiah (Missoula: Scholars, 1979) 182, 183. 
striking from the present point of view. First, because $r \xi c$ can be included within a wider list of roots for representation by a form of $h w b$ ', the argument that 'the wicked' is a technical term appears strained. (There is, of course, no question but that 'the wicked' is a harsh designation; only its technical meaning is at issue here.) Second, the Aramaic usage $b w b$, which may or may not represent $r s^{\prime}$ in Hebrew, is the natural counterpart of

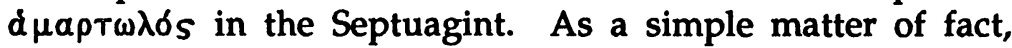
'debtors' can be seen in the Targum of Isaiah as punished by the Messiah (11.4), destroyed by the LORD $(14.4,5)$, but also as capable of repentance $(28.24,25)$, or a species of wicked Gentile (34.2), or another enemy of Jerusalem (54.17).22 Such various usages make any appeal to a univocal or exclusive meaning of the Aramaic term incredible. Quite evidently, a contextual construal of living instances of the word will alone produce an accurate appraisal of its meaning.

Within the Gospels, a coherent language of 'debt' is attributed to Jesus. When, in the Matthean version of the Lord's Prayer, Jesus instructs his followers to ask God, 'forgive us our debts, as we also forgive our debtors', there is no doubt but that the New Testament is preserving an Aramaic idiom (6.12). ${ }^{23}$ Luke only partially preserves the usage: 'Forgive us our sins, as we also forgive everyone who is indebted to us' (11.4). Jesus' usage of the Aramaic idiom is not a mere matter of convention: several of his parables turn on the metaphorical and the literal sense of 'debt', much as in the Targum of Isaiah 50.1 , where the term refers in one breath to money owed, and in another breath to sins before God. ${ }^{24}$

22 Cf. van Zijl (1979) 57, 58; A. Sperber, The Bible in Aramaic III The Latter Prophets (London: Brill, 1962) and B.D. Chilton, The Isaiah Targum. Introduction, Translation, Apparatus and Notes: The Aramaic Bible 11 (Wilmington: Glazier, 1987).

23 Cf. M. Black, An Aramaic Approach (Oxford: Clarendon, 1967) 140.

24 The passage reads as follows:

Thus says the LORD, 'Where is the bill of divorce which I gave your congregation, that it is rejected? Or who had a debt against me, to whom I have sold you? Behold, for your sins you were sold, and for your apostasies your congregation was rejected.'

As in Chilton (1987), italicized words represent innovative departures of the Aramaic rendering from the Hebrew text which underlies it. The first usage of 'debt' corresponds well to the underlying idea in the Masoretic Text, which 
Several instances of parabolic presentation of debt are especially striking. In Matthew 18.23-35, a debtor is said to owe the astronomical sum of ten thousand talents (18.24). When it is borne in mind that the annual imposition of tax upon the whole of Galilee and Peraea amounted to merely two hundred talents (cf. Josephus, Antiquities 17.9.4), the hyperbole involved in the parable becomes readily apparent. The debtor is in no position to repay such a debt, nor is there any credible way in which he could have incurred it. He behaves astoundingly, after his debt is forgiven (v. 27), in a manner all but calculated to trivialize such forgiveness: he refuses to deal mercifully with a colleague who owed him one hundred denarii (vv. 28-30). The latter amount is by no means insignificant; a single denarius has been estimated as the going rate for a full day of labour. ${ }^{25}$ But the contrast with the king's incalculable generosity cannot be overlooked, and the close of the parable makes it unmistakably plain that God's forgiveness demands ours (vv. 31-35). To fail to forgive one's fellow, even when what needs to be forgiven is considerable, is to betray the very logic of forgiveness which alone gives us standing before God.

Two other parables portray, in apparently paradoxical fashion, the inextricable link between divine forgiveness and our behaviour. Within the story of Jesus at the house of a Pharisee named Simon (Lk. 7.36-50), a parable explains why Jesus chose to forgive a sinful woman (vv. 40-43). Of two debtors, the one who has been released from the greater debt will obviously love his creditor more. The sinful woman's great love, therefore, in an outlandish display of affection and honour (vv. 37-38, 44-46), is proof that God had forgiven her (v. 47). Her love is proof of her capacity to be forgiven. ${ }^{26}$ She had

refers to creditors. The second usage (here rendered 'sins') represents 'iniquities' in the Hebrew text, and is also a straightforward, formally correspondent rendering. The point is, however, that both usages together produce a uniquely Targumic juxtaposition of 'debt' in its literal and metaphorical senses.

25 J. Jeremias (tr. S. H. Hooke), The Parables of Jesus (London: SCM, 1963, rev. edn. 1976) 136-9.

26 C. F. D. Moule, "“...As we forgive...": A Note on the Distinction between Deserts and Capacity in the Understanding of Forgiveness', Essays in New Testament Interpretation (Cambridge: Cambridge University Press, 1982) 278$86,282-4$. 
succeeded precisely where the unforgiving servant of Matthew 18 had failed: her actions displayed the value of forgiveness to her. The same logic, developed more strictly in respect of debt, is evident in the otherwise inexplicable parable of the crafty steward (Lk. 16.1-9). The lord praised the steward for his cleverness (v. 8) in reducing the debts of those who owed commodities to the lord (vv. 5-7). The scheme was devised so that the lucky debtors would receive the steward (v. 4) after his lord had followed through on the threat of dismissing the steward for dishonesty (vv. 1, 2). On any ordinarily moral accounting, the steward has gone from bad to worse, and yet his lord praises him (v. 8). Because God is the lord, what would be bribery in the case of any ordinary master's property turns out to be purposeful generosity. The effect of the steward's panic is to fulfill the Lord's desire, ${ }^{27}$ because he is the same as the unforgiving servant's king, the God who forgave the sinful woman.

Jesus' usage of 'debt', therefore, is initially to be understood as an Aramaism. But he appears, on the evidence of the Gospels, to have exploited the metaphorical possibilities of the term in a way which is precedented in the Targum of Isaiah, yet in a characteristically parabolic fashion. The general activity of telling parables, of course, is well attested among early rabbis; ${ }^{28}$ at issue here is not absolute uniqueness, but the relative distinctiveness which distinguishes any significantly historical figure from his contemporaries. A well established theologoumenon of early Judaism spoke not only of debts, but of credit in respect of God. ${ }^{29}$ Jesus appears to have exploited the latter metaphor, as well as the former (cf. Mt. 6.19-21; 19.21; Mk. 10.21; Lk. 12.33, 34; 18.22). But it was in his adaptation of an idiom and theology of 'debt' that Jesus developed a systematic aspect of his message as a whole.

27 B. D. Chilton, A Galilean Rabbi and His Bible. Jesus own interpretation of Isaiah (London: SPCK, 1984) 117-23.

28 B. D. Chilton and J. I. H. McDonald, Jesus and the Ethics of the Kingdom: Biblical Foundations in Theology (London: SPCK, 1987) 31-43.

29 F. Hauck, ' $\delta \phi \in\left(\lambda_{\omega} \ldots\right.$...' TDNT V (ed. G. Kittel, tr. G. W. Bromiley; Grand Rapids: Eerdmans, 1978) 559-66. 
Our analysis of the source and development of Sanders's thesis, then, has revealed two serious weaknesses. He does not offer a credible account of why Jesus came into mortal conflict with his contemporaries, and he distorts the linguistic relationships which are evident among the Masoretic Text, the Septuagint, and the Targumim. Although his challenge of the consensus based upon the contribution of Jeremias is successful, he has not yet developed a viable alternative to it.

\section{Paraenesis}

The language attributed to Jesus, then, makes it apparent that he articulated a message of repentance and forgiveness. To deny such an aspect of his message involves, not only ignoring much material within the Gospels, but actively contradicting it. ${ }^{30}$ The sole ground Sanders has for such a position is that Jesus' opponents accused him of fellowship with 'tax collectors and sinners.' Two factors need to be accounted for in evaluating such a charge. First, it is an accusation, and therefore is not necessarily to be taken at face value. ${ }^{31}$ It could easily be

30 Precisely for that reason, Sanders has taken several steps beyond the criterion of dissimilarity', and is near to invoking a criterion of inversion.

31 The phrase 'tax collectors and sinners' appears within accusations levelled against Jesus in Mt. 9.11 (cf. v. 10)//Mk. 2.16 (cf. v. 15)//Lk. 5.30 (cf. v. 29); Mt. 11.19//Lk. 7.34. Sanders (1985) 92, 206, 263 takes these statements at face value, and so credits the charges as aspects of an historical portrait of Jesus. Indeed, Sanders equates tax collectors with 'quislings, collaborating with Rome' without any discussion whatsoever ([1985] 178). He can only make that bland supposition by discounting those passages in Matthew in which Jesus himself refers to 'tax collectors' in order to convey a sense of irredeemable wickedness (cf. Mt. 5.46; 18.17 and Sanders [1985] 261), and as an emblem of unexpected entry into the kingdom, in association with harlots (cf. Mt. 21.31, 32 and Sanders [1985] 205, 206, 208, 271). Sanders simply dismisses the former set of passages as unhistorical, and takes the latter in a literal sense, as supporting antinomianism. The fact remains, however, that Sanders is unable to draw the conclusion his logic requires, that Jesus commended prostitution. At this point, apparently, Sanders recognizes a metaphor when he reads one. Why he never considered that 'tax collector' belongs to the same order of language remains a mystery. There seems little doubt that in Luke $(3.21 ; 7.29 ; 15.1 ; 18.10,11,13$; 19.1-10) the non-literal sense of the term is exploited. (Cf. also Lk. 3.12-14, in respect of the Baptist!) Such considerations would suggest that the issue of purity does attach to the term, and that a simplistic, historicist decoding of the sort Sanders proposes is not acceptable. There is no doubt of the historical 
voiced, for example, if it were known that some of Jesus' company and/or sympathizers were at some time in their past describable as such. ${ }^{32}$ Second, the frame of reference, within which the accusation is made, is a matter of inference. Sanders has given reasons to doubt that purity, strictly conceived, is the framing concern, and has attempted to replace that perspective with the perceived wickedness of Jesus' followers. Because both of the frames of reference, as proposed, can appeal to no direct evidence to support them, they must - as is the test of every inference - be judged by their degree of plausible agreement with the balance of Jesus' teaching. It has already been observed that Sanders's case fares badly on such a score, although doubt also attaches to the position of Jeremias. Why would the concern of purity per $s e$, at the time the concern of only a minority within Judaism, have occasioned deadly opposition to Jesus?

The form of a possible objection to the notion that a concern for purity lay at or near the centre of controversy is itself instructive. The inference in itself is hardly objectionable; indeed, there is no doubt but that disputes concerning purity are the setting for some of Jesus' teaching. ${ }^{33}$ There is nothing in the least implausible in asserting that Jesus entered into disputes concerning purity, since if it is true that there was little regularity in that regard prior to A.D. 70,

function of tax collecting, but the theological nuances of 'tax collectors and sinners' seem to have escaped Sanders.

32 As a matter of fact, the Synoptic story of Levi's (or Matthew's) call provides the context of the classic accusation of Jesus' association with tax collectors and sinners (cf. Mt. 9.9f.// Mk. 2.13f.// Lk. 15.27f.). The passage for some reason appears 'obviously unrealistic' to Sanders ([1985] 178), although the accusation against Jesus does not (cf. the previous note). The operative principle of selection at this point is not even stated, much less defended.

33 Although it suffers from some of the faults in scholarship correctly identified by Sanders, a lucid discussion of such material is provided in Marcus J. Borg, Conflict, Holiness and Politics in the Teaching of Jesus: Studies in the Bible and Early Christianity 5 (New York: Mellen, 1984) 73-121. Borg also makes the vital connection between Jesus' concept of purity and his attitude toward the Temple (p. 197). Another work of relevance is Roger P. Booth, Jesus and the Laws of Purity. Tradition and Legal History in Mark 7: JSNT Supplement Series 13 (Sheffield: JSOT, 1986). Booth makes a plausible case for the argument that, although it has been subjected to obvious interpretation, the position of Jesus is reflected in the passage. 
controversy would have been the order of the day. The sole objection to a solution along the lines suggested by Jeremias, which objection is the cornerstone of Sanders's case, is that purity was a 'ritual and trivia[1]' matter, and therefore insufficient to arouse great hostility to Jesus.

Sanders actually identifies the reason for which matters ritual could not be seen as 'trivial', but then overlooks its significance. A group within Judaism, know as the haverim, were known for their application to ordinary fellowship at table of the prescriptions of purity which were designed for the Temple. The haverim may plausibly be identified with the Pharisees' in the New Testament, and that identification is the most probable among other possibilities (although Sanders disputes this). ${ }^{34}$ In any case, Sanders is surely correct in saying that the view of such groups prior to 70 was not representative of Judaism generally. A clear recognition of that should have enabled Sanders to see that the charges in respect of Jesus' association with the impure of Israel might well have been exaggerated in the period after A.D. 70. Such accusations served the Church of the Diaspora extremely well, and could be used to good effect in the address of Gentiles. ${ }^{35}$ But an even more telling point emerges at this juncture: the likely frame of reference for disputes concerning purity, aside from the practices of haverim, was the cult in the Temple. An alteration of one's understanding of purity necessarily involved cultic implications.

34 Sanders is less qualified in his rejection of this view in his book, cf. (1985) 188, than in his article, cf. (1983) 14, 15. The difference is, however, tonal, rather than substantive. In neither contribution does Sanders deal with Neusner's strongest argument: the shape of the Mishnah itself (cf., for example, Judaism. The Evidence of the Mishnah [Chicago: University of Chicago Press, 1981]). Sanders focuses instead on Neusner's earlier work, which is more interesting for the development of techniques of historical inquiry than for the substantive characterization of literatures and movements, as in his later works. Both Borg and Booth (cf. n. 33) acept Neusner's portrait of the Pharisees, as the outcome of a much fuller and critical discussion than Sanders accords the subject. Sanders's rejection of Neusner's account is less than convincing, and his own, highly general definition of the Pharisees is simply too broad. The Pharisees were not unique in their concern for an oral Torah, as writings from Qumran, Alexandria, and the many loci of the movement of Wisdom (inter alia) make clear.

35 Just this point is demonstrated by Booth, in the work discussed in n. 33. 
Such an adjustment in the construal of purity is one characteristic of Jesus' teaching in the Gospels, and corresponding implications in respect of the cult are not wanting. Examples may include Jesus' cleansing of the leper (Mt. 8.1-4; Mk. 1.40-45; Lk. 5.12-16, cf. Mt. 10.8; 11.5; Lk. 4.27; 7.22; 17.11-19) and his dispute concerning purity (Mt. 15.1-20; Mk. 7.1-23; Lk. 11.37-41). The former instance explicitly refers to the priesthood, as established by Moses, to which Jesus directs the leper, in order to attest his cleanness. The cultic hierarchy is therefore challenged to accept Jesus' verdict in the vignette. The latter passage offers a global view of what cleanses, and argues that defilement is fundamentally a matter of disposition, not washing; such a policy is obviously at odds with the normal practice in the case of the vessels of the Temple. At this juncture, Jesus' stance in respect of purity might be taken, no longer as sui generis, but as one aspect of his halakhah for the Temple. His cultic teaching in Matthew includes reference to the taking of oaths (23.16-22), instructions for the offering of sacrifice $(5.23,24)$, and an elaborate story which relates to the payment of the half shekel (17.24-27; cf. 23.23 and Lk. 11.42). All of those passages are uniquely Matthean, and yet are widely accepted as relating to the substance of Jesus' attitude toward the Temple. Multiply attested traditions - Jesus' teaching in respect of a widow's offering (Mk. 12.41-44; Lk. 21.1-4), his occupation of the holy precincts (Mt. 21.12, 13; Mk. 11.15-17; Lk. 19.45, 46; Jn. 2.13-17), his discourse concerning the destruction of the Temple (Jn. 2.19; Mt. 26.61; Mk. 14.58) - consistently reinforce the impression that a cultic halakhah was promulgated by Jesus. ${ }^{36}$ The well known, public

36 Cf. B. D. Chilton, 'Shebna, Eliakim, and the Promise to Peter', Targumic Approaches to the Gospels. Essays in the Mutual Definition of Judaism and Christianity: Studies in Judaism (New York and London: University Press of America, 1986), 63-80. Precisely because Sanders refuses to take Jesus' sayings and actions in respect of the Temple in the cultic terms which are natural, he must take Jesus' occupation of the Temple as an entirely symbolic act. As Dunn points out in his review (cited in $\mathbf{n}$. 37), it is scarcely self-evident that Jesus' act was intended and understood to predict the Temple's destruction (p. 512). In this instance, Sanders cuts away the natural, cultic context of Jesus' act, and introduces his own notion of what Jesus' 'restoration eschatology' concerned; (cf. Sanders [1985] Chapter 3): he actually suggests 'that the saying about the temple and the action should be taken together, and that both point towards 
events surrounding his death would suggest that Jesus' halakhah was sufficiently insistent, challenging, and forceful as to demand a drastic response from those charged with the rigorous conduct of the cult.

Jesus' offence to some of his contemporaries lay neither in his break with a small group of especial, pious purity, nor in an antinomian denial of repentance. Scholars of the New Testament, to some extent under Sanders's able guidance, have largely freed themselves of the anachronistic portrait of Jesus as a single-handed reformer of Jewish formalism. But a second repentance is now necessary. The persistent reflex is still apparent, of construing Jesus' distinctive message, and his offence to some, in ideological terms. But the very manner of his death, and its particular agency, would rather suggest that Jesus' habit of teaching an idiosyncratic understanding of purity and sacrifice finally brought him into a mortal conflict.

The historical Jesus who has finally emerged from the hermeneutical vagaries of the post-war period is an inference from our literature; he is what we must posit in order to understand the documents to hand. That is the postBultmannian premise from which Sanders operates, and the seriousness with which his book has been received ${ }^{37}$ would

"eschaton," not "purity"' (Sanders [1985] 89). A recent article by J. Duncan M. Derrett (No Stone Upon Another: Leprosy and the Temple', JSNT 30 [1987] 3-20) successfully demonstrates that the entire complex of material may be construed in terms of purity. Jacob Neusner, in a treatment which is shortly to be published, sees Jesus' act as an attempt directly to substitute his own, eucharistic cult for that of the Temple. Whatever else may be said of the contributions of Derrett and Neusner, they at least have the virtue that they take the immediate terms of reference of historical actions seriously, and do not reduce them to symbols of an ideology with which they have but a tenuous connection. A work which Sanders could not have referred to, but which militates against his position is Roger P. Booth, op. cit. (n. 33). Booth and I entered into a considerable correspondence concerning his volume. Elements of his case appeared to me grounded rather more in the assumption than in the demonstration of authenticity. More seriously, Booth tends to treat of purity in the abstract, rather than as focused clearly upon the Temple.

37 Cf. the reviews of P. Alexander, JJS 37 (1986) 103-106; J.J. Collins, JR 66 (1986) 203-4; J.D.G. Dunn, JTS 37 (1986) 510-513; D. Senior, CBQ 48 (1986) 569-571. Of these reviews, only Dunn's points out that, in his construal of Jesus in eschatological terms, Sanders builds directly on the contribution of Schweitzer, and therefore fails to do justice to the present aspect of the kingdom in Jesus' preaching. That is, as Dunn points out, an unfortunate failure, since Sanders 
suggest that discussion of Jesus in critical terms might commence again, without excessive reversion to solipsistic proofs from the interpreter's own biases. Sanders's volume is also a landmark, in that the construal of Jesus within early Judaism is shown to be viable, and necessary, within the historian's task. But the burden of these remarks has been to suggest that there is also a negative lesson to be learned from Sanders: Jesus' distinctiveness, and therefore his offensiveness, cannot be explained in ideological terms alone. Early Judaism was certainly varied, but the variation was not chiefly worked out dogmatically, as in Protestant denominationalism. As long as the Temple stood, it was the benchmark of all contemporaneous Judaisms, in respect of which they defined themselves by involvement, withdrawal, and criticism. That Judaism which became Christianity manifests the same dynamic, and the distinctive, cultic halakhah of its pre-eminent teacher appears to have been a central influence. The historical Jesus, so understood, is fully capable of speaking, and his language will be not of transcending Judaism, or of denying a particular party of Judaism, or of a philosophical redefinition of repentance. His language will be of purity, sacrifice, and atonement, of entering the narrow gate of a Temple not made with hands.

makes his reconstruction of Jesus' message in this regard into a criterion of authenticity. It might also be noted that, although Sanders claims some originality for the procedure ([1985] 5), T.W. Manson championed the method of taking events as the determining context of sayings (cf. The Teaching of Jesus [Cambridge: Cambridge University Press, 1955] 12-15). Both Manson and Sanders fail adequately to account for the simple reality that events and actions require quite as much interpretation as sayings do, in order to be understood. Particularly, a person's action or gesture will be totally misunderstood, when placed in an alien context (cf. $n$. 36). When the derivative nature of Sanders's portrait of Jesus' eschatology and of Sanders's method are perceived, it becomes plain that his construal of repentance in Jesus' teaching is in fact his chief claim upon originality. 